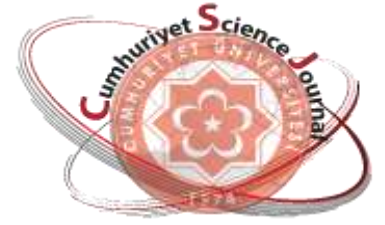

e-ISSN: 2587-246X

ISSN: 2587-2680

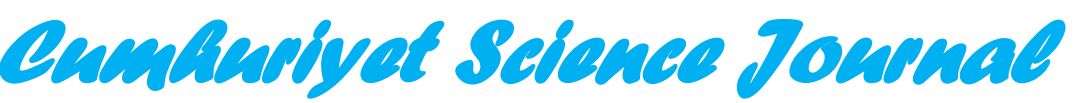

$\cos$

Cumhuriyet Sci. J., Vol.40-1(2019) 265-274

\title{
Investigation of Surface Temperature Differentiation of Fagus and Quercus Stands by Using Landsat Images
}

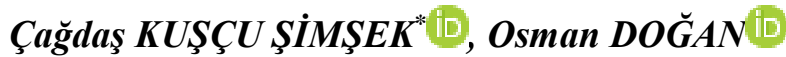 \\ Sivas Cumhuriyet University, Faculty of Engineering, Geomatic Engineering, Sivas, TURKEY
}

Received: 03.07.2018; Accepted: 04.03.2019

http://dx.doi.org/10.17776/csj.440198

\begin{abstract}
While climatic features of regions affect the variety of tree species and their structures, the vegetation structures of the regions are effective on micro climate. In this study, thermal differentiations in the Fagus and Quercus stands which are homogenous in structure and are found within the boundaries of Mercanköşk Forest Sub-District Directorate in Şile are presented.

The surface temperature data which is obtained by Landsat TM-5 and Landsat 8 - ETM thermal images during 2011, 2013, 2014 and 2015 is compared statistically in relation to data obtained from the stand. According to the results obtained, it has been found out that there is a difference of surface temperature up to $2.4^{\circ} \mathrm{C}$ among tree types. This surface temperature difference which is within the boundaries of forest subdistrict directorate having similar regional features has an undeniable effect in terms of climate. It has been thought that using this information as a regional inventory in the preparatory studies within the scope of tackling with global warming will be effective on the success to be achieved.
\end{abstract}

Keywords: Landscape Planning, Micro climate, Remote Sensing, Fagus, Quercus.

Landsat Görüntüleri Kullanılarak Kayın ve Meșe Meșcerelerinin Yüzey

\section{Sıcaklığı Farklılığının İncelenmesi}

Özet. Bölgelerin iklimsel özelliklerinin, ağaç türlerinin çeşitliliğini ve yapısal özelliklerini etkilemesine karşın bitki örtüsü yapısı da mikro iklim üzerinde etkili olmaktadır. Bu çalışmada, bu bilgiye dayanarak, Şile'nin Mercanköşk Orman İşletme Şefliği sınırı içerisinde kalan ve homojen yapı sergileyen kayın ve meşe meşcereleri ele alınarak yüzey sıcaklığg farklılıkları ortaya konulmaya çalışılmıştır

2011 Landsat TM-5 ve 2013, 2014 ve 2015 yıllarına ait Landsat 8 - ETM termal görüntüleri üzerinden elde edilen yüzey sıcaklığı bilgileri, meşcere verisi ile ilişkilendirilerek istatistiksel olarak karşılaştırılmıştır. Elde edilen sonuçlara göre, iki ağaç türüne ait homojen meşcere alanları arasında $2.4^{\circ} \mathrm{C}$ 'ye varan yüzey sicaklığı farklarının oluştuğu tespit edilmiştir. Bölgesel özelliklerin hemen hemen benzer olduğu şeflik sınırları içerisinde oluşan bu sıcaklık farkı, iklimsel açıdan gözardı edilemeyecek bir etki yaratmaktadır. Özellikle küresel ısınmayla mücadele kapsamında yapılan hazırlık çalışmalarında, bu bilgilerin bölgesel envanter olarak kullanılmasının, elde edilecek başarı üzerinde etkili olacağı düşünülmektedir.

Anahtar Kelimeler: Peyzaj Planlama, Mikro iklim, Uzaktan Algılama, Kayın, Meşe.

\section{INTRODUCTION}

Recently, the world of science has focused on the anticipated destructions emerging as a result of the global climate changes and has concentrated on developing action plans and adaptation strategies to struggle with probable scenarios. The issue, which is debated on global warming in the macro scale, is debated on the combined effects of global climate changes and urban climates, which change due to urbanization, and anthropogenic effects in the micro scale. Globally, the factors which have an influence on global climate changes, locally 
have an influence on urban climate and these factors increase the climatic comfort conditions of the cities especially which are on the tropical and mid-latitudes above the critical level [1]. Thus, man who is not in the scope of climatic comfort criteria may encounter with fatal consequences frequently. When current examples are examined, the seriousness of the situation becomes more obvious. Heat waves which are encountered more frequently due to global climate changes have caused the death of 70.000 people in Europe in the summer of 2003 [2], almost 2500 people in 15 days in India in 2015 [3] and 700 people in a week in France in 2015 [4]. Such circumstances have led this issue to be handled under the scope of natural disaster. Besides, the temperatures' increasing above the seasonal normals causes an increase in electric consumption together with agricultural irrigation. For instance it was stated that the increasing electric consumption due to extremely hot weather conditions all over Turkey on 28th July 2015 reached to $866,653 \mathrm{MWh}$ and broke a record and that the electric bill for a day was nearly 333 million lira [5, 6]. That is, increasing human population with its anthropogenic effects together with increasing climatic pressure pose a threat both for health and economy.

Today, humankind is under the pressure of both global climate changes and anthropogenic effects especially in the big cities in the mid latitude. These two incidents have an interdependent and transitive nature; not only they are influenced by the same factors but also they cause pressure on each other. As stated in the abovementioned examples, the incidents, which are not in the scope of comfort criteria, may have fatal dangers. During this process, while man is struggling with global climate changes in the macro scale, he has to struggle with protecting climatic structures of the cities in the micro scale. Heat waves, which are considered as natural disasters by most developed countries, have led to the development of strategies and the preparation of action plans. The preparation process is supported by many scientific studies.
Turkey, where is situated in the mid latitude, is rather unprepared for this problem. Each region has its own climatic characteristics with its geographical location, wind direction and speed, topography, ecological features, surface elements, land use, urban features, population etc. Thus, the strategies, which will be developed, should be prepared by taking the inner dynamics of that region into consideration. This increases the need for regional studies, which will evaluate various factors on climate. Besides, this complex structured problem brings along the need for multidisciplinary studies.

While climatic features of a district have an influence on the vegetation, vegetation also has an influence on the climatic features. The vegetation climate relationship, which influences each other and has a dual interaction, necessitates the development of dual strategies.

In the upcoming years, considering droughts and natural deteriorations when predicting how the climate change in the new climate scenarios will affect forest dynamics and tree adaptations it has become necessary to identify the growth patterns and dispositions of trees under the stand or tree scale [7]. On the other hand, to obtain more fruitful results in the struggle with macro and micro climate changes, conscious forestation efforts which considers structural features of the vegetation have become more important. For instance, the areas covered by leaves from different types of trees can create a temperature differences up to $4^{\circ} \mathrm{C}-5^{\circ} \mathrm{C}$ in the micro climate [8].

On the other side, green spaces contribute to the reduction of greenhouse effects by cooling the weather, increasing relative humidity, providing clean air, filtering the air and producing oxygen. The soil and the vegetation first absorb the heat and then send it away by vaporization [9]. These features increase the adaptation ability to climatic changes. Perspiration of the vegetation that retains water or the vaporization in the soil are important factors to cool the air and they can create a difference in temperature up to $1^{\circ} \mathrm{C}-5^{\circ} \mathrm{C}$. The air 
stream moving above the trees contribute to cooling the environment by carrying the cool air to the treeless districts [10].

Vegetation, which is used as a natural source to cool the cities decreases the energy amount necessary to cool the air therefore, decreases the use of fossil fuels necessary for electric production. The studies conducted in Atlanta (USA) reveal that in 1975 trees sent 13,6 million tonnes of pollutant away from the atmosphere in one year and made a contribution of 75 million dollars and in 1996 these values were limited to respectively 8,6 million tonnes and 47 million dollars [11]. According to the same study, thanks to the advantages provided by the trees, energy worth 2,8 million dollars is saved. When the issue is dealt with from the point of view of utility theory of value it is obvious that making use of green spaces effectively to struggle with macro and micro climate changes provides great benefits economically.

Today, the importance of conscious forestation is increasing gradually to make the most of forests and green spaces which are necessary natural sources against $\mathrm{CO}_{2}$ emission speed because of rapidly increasing population, urbanization, consumption and anthropogenic effects.

In the current study, thermal differences are tried to be investigated by examining Fagus and Quercus stands in the same closeness and growth age, and which have a homogeneous structure in the Şile Mercanköşk Forest Sub-district Directorate, by using remote sensing techniques. The obtained results are aimed to be used in the forestation of both city centres and urban periphery which has an important role in minimizing the temperature rise occurring in the micro climatic structures of the cities and forestation of the district.

\section{MATERIALS AND METHODS}

\subsection{Study Area}

The study was carried out within the borders of İstanbul Şile Mercanköşk Forest Sub-district
Directorate. It's neighbours are Yeşilvadi in the east, Ağva in the west, Şile Forest Sub-district Directorate in the North. Within the borders of the directorate there are 9460 ha Quercus, 2470 ha Fagus, 130 ha carpinus, 201 ha pinus pinea homogenous stands. Together with the other stands there are nearly 12458.3 ha forest areas in sum (Figure 1).

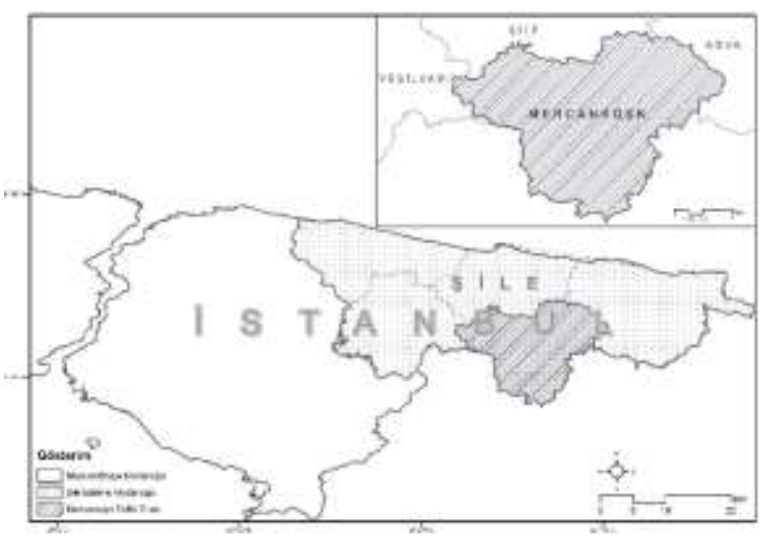

Figure 1. The study area.

Setting is important in certain aspects to reach a reliable result. First of all overall climate features should not have a lot of difference depending on sub-factors and secondly climatic features between homogenous stands of different types should be revealed. In this context, the directory is preferred because the borders of the directory consist of small units and regional characteristics do not have a lot of differences. Besides, anthropogenic effects are decreased by choosing the setting somewhere far away from the city centre.

A district within the borders of the metropolitan İstanbul which has the $1 / 5$ population of the country is preferred as the setting because the study is thought to be a preparation for the landscape practices against increasing climatic brittleness due to the city's rapid growth.

\subsection{Data}

In the study, satellite imaging and data from the stand are used. In the selection of satellite images, the images from the summer period are used because heat islands are detected more easily then. Besides, since the stand data belongs to 2012, four 
years when change of area usage is in the acceptance boundary is preferred. Accordingly, 19.07.2011 Landsat 5-TM and 30.07.2013, 10.07.2014, 29.07.2015 LANDSAT 8 OLI/TIRS data belonging to the area is used. Landsat 2012 image belonging to the area is not used since it could not be found.

As the stand data, data from 2012 belonging to Mercanköşk Forest Sub-district Directorate is used. However, since it is thought that the differentiation of closeness and growth age may create a difference micro-climatically, the areas which have similar closeness and growth age are used together. As a result of this elimination, homogenous Fagus and Quercus stands which have similar closeness and growth age are used.

\subsection{Method}

The basic hypothesis of the study is that different tree species have different thermal characteristics which can affect the micro-climatic structure. Climate studies are both multi-parameter studies, which evaluate issues using different scales and details, and have time and period differences. In the climatic studies which have a complex structure, the selection of scale, parameter and period have a great importance for the accuracy of the analysis. Besides, the analysis method of this complex structure is also an important factor influencing the accuracy of evaluation.

In the studies, it is necessary to approach the topic with a far-reaching point of view and to create real-like modelling with up-to-date data. In this respect, geographical information systems (GIS) and remote sensing methods are important tools of the processes such as analysis, evaluation, decision-making and developing strategies. They are necessary tools for climatic studies because they not only pave the way for observing very large areas and identifying problematic points but also they have features such as proving a holistic approach for planning, enabling the integration of multiple data, being updatable and enabling time changes [12]. Especially in the climate studies another adavantage of remote sensing is that it enables visualizing heat on large areas and obtaining a great amount of thermal data at a sitting [9]. Furthermore it also enables measuring many factors about vegetation such as perspiration, vegetation stress, NDVI and canopy temperature [8]. In the light of this information, in this study, which used GIS and remote sensing effectively the workflow, consisted of image processing, arrangement of the stand data on the database, association of thermal images with the stand data, statistical analysis, results and forming planning suggestions.

The study is carried and discussed on the basis of surface temperatures. Surface temperatures are different from air temperatures in terms of measurement techniques. Remote sensing techniques are used as the most effective method for determining surface temperatures [13, 14]. However, there are also many studies that show the high correlation between air temperatures and surface temperatures which are obtained from remote sensing techniques [15-18].

On the other hand, this study is mandatorily handled in this context, because it involves the period between the years 2011-2015 and because we can't make any measurements parallel to past with terrestrial measurements. So, the use of remote sensing techniques have been deemed suitable for this study taking support from researches both mentioned and not mentioned above.

Before image processing, calibrations of the images of Landsat TM-5 and Landsat-8 OLI were made according to the landsat parameters which were given in metadata. By this way, spectral radiance values $\mathrm{L}_{\lambda}\left(\mathrm{W} /\left(\mathrm{m}^{2} * \mathrm{sr} * \mu \mathrm{m}\right)\right)$ were obtained [19].

In order to calculate surface temperature, emissivity and NDVI values, which highlight reflection characteristics of surface elements, are used. Emissivity emerges with the electromagnetic wave releasing ability of the objects. The emissivity value is not only dependent on the creation of objects but also to 
the surface roughness, physical properties of the object, and angle and wavelength. On the large scale, it is very difficult to calculate surface emissivity values, and this process is usually achieved based on certain hypothesis. Van de Griend and Owe [20] by doing a series of thermal band emissivity and normalized vegetation index (NDVI) calculations (eq. 1) in the natural environment, have found that there is a high correlation logarithmic connection between them (eq. 2). Generally the emissivity value of the dry soil is lower since the vegetation is more humid. The $\varepsilon$ value is calculated based on Van's formula. Then, according to the radiative transfer equation (eq. 3) given by Jiménez-Muñoz et al. [21], the radiation brightness values were calculated. Then by using eq. 4 , the land surface temperature $\left(T_{\mathrm{s}}\right)$ values were calculated and land surface temperature images (Figure 2) were obtained.

NDVI $=($ Band4 - Band 3$) /($ Band4 + Band 3$)$

$\varepsilon=1.0094+0.047 \mathrm{Ln}(\mathrm{NDVI})$

$\mathrm{L}_{\lambda}=\left[\varepsilon_{\lambda} \mathrm{L}_{\lambda}\left(\mathrm{T}_{\mathrm{s}}\right)+\left(1-\varepsilon_{\lambda}\right) \mathrm{L}_{\lambda \mathrm{atm}} \downarrow\right] \tau+\mathrm{L}_{\lambda \mathrm{atm} \uparrow}$

$\mathrm{T}_{\mathrm{s}}=\mathrm{K}_{2} / \ln \left(\left(\mathrm{K}_{1} / \mathrm{L}_{\lambda}\right)+1\right)$

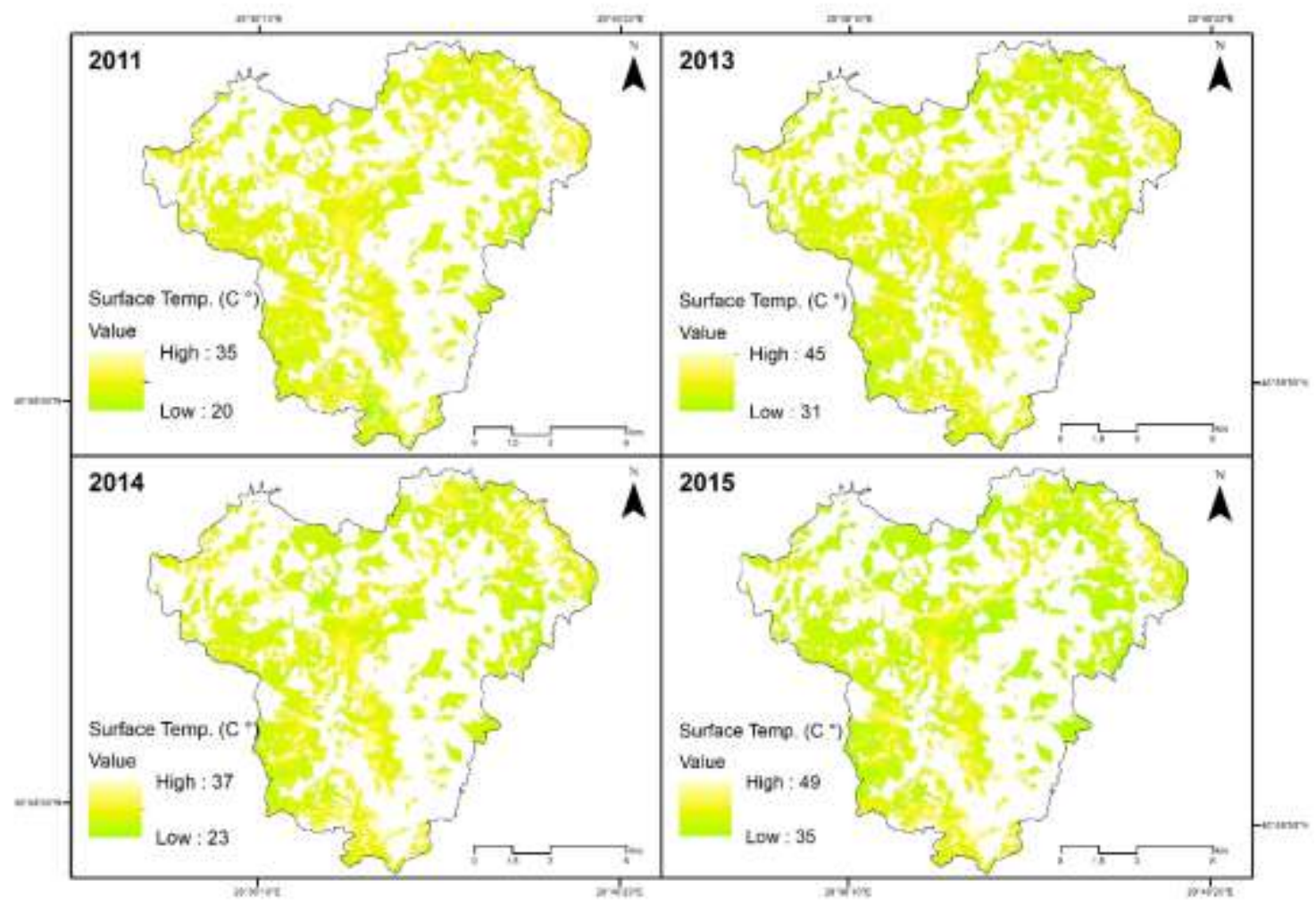

Figure 2. Years of surface temperature images.

In this study, the possible changes in surface temperatures are considered due to the instantaneous meteorological situations or different exogenous factors by using the images of 4 different years and by examining the correlations of these images with each other. Between the surface temperatures of these images, high correlations were determined in the range from 0.701 to 0.866 at 0.01 significance level.
These high correlations show that the images can be evaluated together.

Subsequently, the effects of the elevation, slope and the aspect values on surface temperatures are examined by regression analysis. The results show that, the topographic factors have no significant effect on surface temperatures. So, based on these results, topographic factors are not used as parameters. 
As stand data, homogenous structured areas, which are obtained by making use of stand codes in the database are used (Figure 3).

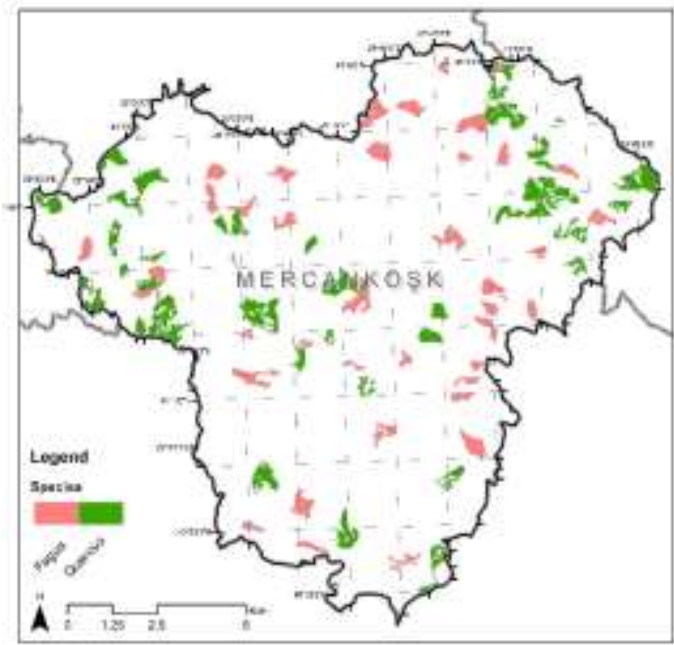

Figure 3. Fagus and Quercus stands which are used.

In this area, homogenous stands of Pinus Pinea, Carpinus, Fagus and Quercus are observed. However, in order to identify the climatic effect created by the vegetation better, taking closeness and growth age, which will make a difference into consideration, Fagus and Quercus stands with a similar structure, are assessed. In the area the closeness in Fagus stands is 3, growth ages are 01-2-3; the closeness in the Quercus stands is 0-23 , growth ages are $0-1-2-3-4$. Therefore, the study is conducted by taking closeness 3 and growth ages 1-2-3, which are common values in both vegetation species. Since the area proportion of Fagus stands is rather lower than the area proportion of Quercus stands, areas with a similar size near the Fagus stands are selected as sample Quercus areas. In this study, which is evaluated based on pixels, data base is formed by associating thermal images belonging to 4 different years to the stand data and surface temperature differentiation of Fagus and Quercus stands is examined by using independent variables $t$ test with a confidence interval of $\% 95$.

\section{RESULTS AND DISCUSSION}

According to the results obtained from $\mathrm{T}$ tests, the average surface temperature of Quercus and Fagus stands differentiate from each other within all years of the study. The comparison table which is prepared based on the results of the $T$ test $\left(t_{0,05: d f}\right.$ $=\mathrm{t}$ ) conducted to compare the surface temperature grades of Quercus and Fagus stands can be seen below (Table 1). When the significance level of the results are examined, the Quercus and Fagus stands have significantly differentiated from each other in terms of thermal structure in all years except for the 2013 year which have a closeness level of 3 and growth age level 3 (Table 2). Average surface temperature values of the years 2011 - 2013 - 2014 and 2015 can be seen in Table 2 and surface temperature differences between the two species and their graphical illustrations are shown in Table 3.

When the average temperature values and the temperature differences between the two groups are examined it has been identified that the growth ages of the trees are influential on the thermal characteristics of tree species; the Fagus stands are nearly $0.7^{\circ} \mathrm{C}-1.6^{\circ} \mathrm{C}$ cooler than the Quercus stands in the $1^{\text {st }}$ and $2^{\text {nd }}$ growth ages however the Quercus stands are $1.1^{\circ} \mathrm{C}-2.4^{\circ} \mathrm{C}$ cooler than the Fagus stands in the $3^{\text {rd }}$ growth age.

Different plant species exhibits different thermal characteristics that can be used to control and regulate indoor and outdoor thermal comfort [22], [23]. In recent years, researches on this subject have gained importance. Some of these studies applied with terrestrial measurements and some of them applied with thermal cameras. For instance, a study conducted by Leuzinger and Körner [8] which compared the surface temperatures measured with thermal cameras, the maximum difference was found $4.5^{\circ} \mathrm{C}$ between Larix and Tilia species. In the same study, $2.2^{\circ} \mathrm{C}$ mean temperature difference was found between Quercus and Fagus species. According to Lin and Lin's [24] research results, Elastic being the most effective tree in the sense of cooling effect, followed by Parvifolia and Microcarpa. The results of analysis revealed that there were significant differences in the magnitude of temperature reduction, which ranged from $0.64{ }^{\circ} \mathrm{C}$ to $2.52{ }^{\circ} \mathrm{C}$, under different tree groups. In another study by Abreu-Harbich et al. [25], a cluster of $S$. Siamea, C. Pluviosa and T.Tipu trees had the best 
cooling effects with their shading reducing the air temperature by $5.9^{\circ} \mathrm{C}-11.5^{\circ} \mathrm{C}$ was found.

According to the results obtained from this study, it has been identified that the Quercus and Fagus species in the $3^{\text {rd }}$ growth age can create $1.1^{\circ} \mathrm{C}-$ $2.4^{\circ} \mathrm{C}$ surface temperature difference which can also effect the micro-climate. This range is compatible with the results of Leuzinger and Körner's [8] study where Quercus stands mean surface temperature was $2.2^{\circ} \mathrm{C}$ cooler than Fagus stands. On the other hand, $1^{\text {st }}$ and $2^{\text {nd }}$ growth ages results were found different from the $3^{\text {rd }}$ growth age (Table 3). According to this, Fagus stands are nearly $0.7^{\circ} \mathrm{C}-1.6^{\circ} \mathrm{C}$ cooler than the Quercus stands. This dual result can be caused by the soil effect which increases if the plants have not reached sufficient growth level. But, more detailed studies supported by terrestrial and remote sensing measurements are needed to clarify the causes of this dual situation.

In addition, it must be mentioned here that the stand data used in the study was accepted as correct due to it was obtained via the Forest Directorate. Therefore, it should be noted that possible errors in stand data will affect the results of the study.

Table 1. Descriptive statistics.

\begin{tabular}{|c|c|c|c|c|c|c|c|c|c|c|}
\hline \multirow{2}{*}{$\begin{array}{c}\text { Closeness } \\
\text { / Growth } \\
\text { Age }\end{array}$} & \multirow[b]{2}{*}{ Year } & \multirow[b]{2}{*}{ Species } & \multirow[b]{2}{*}{$\mathrm{N}$} & \multirow[b]{2}{*}{ Mean } & \multirow{2}{*}{$\begin{array}{c}\text { Std. } \\
\text { Deviation }\end{array}$} & \multirow{2}{*}{$\begin{array}{l}\text { Std. } \\
\text { Error }\end{array}$} & \multicolumn{2}{|c|}{$\begin{array}{l}95 \% \text { Confidence } \\
\text { Interval for Mean }\end{array}$} & \multirow[b]{2}{*}{ Minimum } & \multirow[b]{2}{*}{ Maximum } \\
\hline & & & & & & & $\begin{array}{l}\text { Lower } \\
\text { Bound }\end{array}$ & $\begin{array}{l}\text { Upper } \\
\text { Bound }\end{array}$ & & \\
\hline \multirow{6}{*}{ 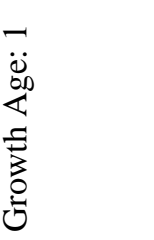 } & \multirow[t]{3}{*}{ Ts 2015} & Fagus & 4233 & 37.8240 & 1.48307 & .02279 & 37.7793 & 37.8687 & 35.62 & 48.83 \\
\hline & & Quercus & 6157 & 38.6111 & 1.43125 & .01824 & 38.5754 & 38.6469 & 36.01 & 46.61 \\
\hline & & Total & 10390 & 38.2905 & 1.50313 & .01475 & 38.2616 & 38.3194 & 35.62 & 48.83 \\
\hline & \multirow[t]{3}{*}{ Ts 2014} & Fagus & 4233 & 29.5603 & 1.50698 & .02316 & 29.5149 & 29.6057 & 23.97 & 38.96 \\
\hline & & Quercus & 6157 & 30.5653 & 1.72338 & .02196 & 30.5223 & 30.6084 & 24.34 & 39.00 \\
\hline & & Total & 10390 & 30.1558 & 1.71140 & .01679 & 30.1229 & 30.1888 & 23.97 & 39.00 \\
\hline \multirow{6}{*}{ 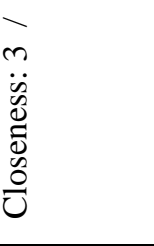 } & \multirow[t]{3}{*}{ Ts 2013} & Fagus & 4233 & 37.3802 & 2.02782 & .03117 & 37.3191 & 37.4413 & 32.16 & 49.04 \\
\hline & & Quercus & 6157 & 39.0060 & 1.87797 & .02393 & 38.9591 & 39.0530 & 33.74 & 49.01 \\
\hline & & Total & 10390 & 38.3436 & 2.09836 & .02059 & 38.3033 & 38.3840 & 32.16 & 49.04 \\
\hline & \multirow[t]{3}{*}{ Ts 2011} & Fagus & 4233 & 27.2850 & 1.79389 & .02757 & 27.2309 & 27.3391 & 24.02 & 39.31 \\
\hline & & Quercus & 6157 & 28.7610 & 2.37858 & .03031 & 28.7016 & 28.8204 & 21.51 & 40.16 \\
\hline & & Total & 10390 & 28.1597 & 2.27801 & .02235 & 28.1159 & 28.2035 & 21.51 & 40.16 \\
\hline \multirow{6}{*}{ 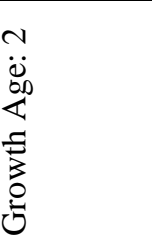 } & \multirow[t]{3}{*}{ Ts 2015} & Fagus & 762 & 38.3181 & 2.28832 & .08290 & 38.1553 & 38.4808 & 36.00 & 47.52 \\
\hline & & Quercus & 860 & 39.4200 & 2.43673 & .08309 & 39.2569 & 39.5831 & 35.67 & 46.04 \\
\hline & & Total & 1622 & 38.9023 & 2.43052 & .06035 & 38.7839 & 39.0207 & 35.67 & 47.52 \\
\hline & \multirow[t]{3}{*}{ Ts 2014} & Fagus & 762 & 29.7377 & 2.06851 & .07493 & 29.5906 & 29.8848 & 27.37 & 38.79 \\
\hline & & Quercus & 860 & 31.2395 & 1.91890 & .06543 & 31.1111 & 31.3679 & 28.15 & 37.46 \\
\hline & & Total & 1622 & 30.5340 & 2.12652 & .05280 & 30.4304 & 30.6375 & 27.37 & 38.79 \\
\hline \multirow{6}{*}{$\begin{array}{l}\bar{m} \\
\ddot{D} \\
\ddot{D} \\
\dot{0} \\
\stackrel{0}{0} \\
\stackrel{0}{0}\end{array}$} & \multirow[t]{3}{*}{ Ts 2013} & Fagus & 762 & 37.5456 & 2.27976 & .08259 & 37.3835 & 37.7078 & 35.16 & 46.22 \\
\hline & & Quercus & 860 & 38.5041 & 2.44960 & .08353 & 38.3402 & 38.6681 & 34.35 & 48.29 \\
\hline & & Total & 1622 & 38.0538 & 2.41841 & .06005 & 37.9361 & 38.1716 & 34.35 & 48.29 \\
\hline & \multirow[t]{3}{*}{ Ts 2011} & Fagus & 762 & 27.3950 & 2.08832 & .07565 & 27.2465 & 27.5435 & 24.06 & 35.86 \\
\hline & & Quercus & 860 & 28.1542 & 2.35573 & .08033 & 27.9965 & 28.3118 & 22.99 & 37.05 \\
\hline & & Total & 1622 & 27.7975 & 2.26534 & .05625 & 27.6872 & 27.9078 & 22.99 & 37.05 \\
\hline \multirow{12}{*}{ 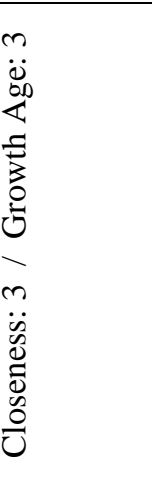 } & \multirow[t]{3}{*}{ Ts 2015} & Fagus & 56 & 41.0003 & 2.69988 & .36079 & 40.2773 & 41.7234 & 37.22 & 46.31 \\
\hline & & Quercus & 69 & 38.5774 & 1.15182 & .13866 & 38.3007 & 38.8541 & 37.23 & 42.74 \\
\hline & & Total & 125 & 39.6629 & 2.32899 & .20831 & 39.2506 & 40.0752 & 37.22 & 46.31 \\
\hline & \multirow[t]{3}{*}{ Ts 2014} & Fagus & 56 & 32.1892 & 2.44994 & .32739 & 31.5331 & 32.8453 & 29.40 & 37.65 \\
\hline & & Quercus & 69 & 30.6534 & .94139 & .11333 & 30.4273 & 30.8795 & 29.22 & 33.25 \\
\hline & & Total & 125 & 31.3414 & 1.93294 & .17289 & 30.9992 & 31.6836 & 29.22 & 37.65 \\
\hline & Ts 2013 & Fagus & 56 & 39.4941 & 2.40828 & .32182 & 38.8491 & 40.1390 & 36.37 & 44.03 \\
\hline & & Quercus & 69 & 39.1819 & 1.40033 & .16858 & 38.8455 & 39.5183 & 37.20 & 43.49 \\
\hline & & Total & 125 & 39.3218 & 1.91628 & .17140 & 38.9825 & 39.6610 & 36.37 & 44.03 \\
\hline & Ts 2011 & Fagus & 56 & 29.3145 & 2.39596 & .32017 & 28.6729 & 29.9561 & 26.60 & 32.73 \\
\hline & & Quercus & 69 & 28.1235 & 1.43669 & .17296 & 27.7784 & 28.4687 & 25.77 & 32.06 \\
\hline & & Total & 125 & 28.6571 & 2.00792 & .17959 & 28.3016 & 29.0126 & 25.77 & 32.73 \\
\hline
\end{tabular}


Table 2. Average surface temperature values and average differences of Fagus and Quercus stands by years, closure groups and growth ages.

\begin{tabular}{|c|c|c|c|c|c|c|c|}
\hline \multirow{2}{*}{$\begin{array}{l}\text { Closeness / } \\
\text { Growth Age }\end{array}$} & \multirow{2}{*}{ Year } & \multicolumn{2}{|c|}{ Mean } & \multirow{2}{*}{$\begin{array}{c}\text { Mean Difference } \\
\text { Quercus - Fagus } \\
\Delta \mathrm{T}\left({ }^{\circ} \mathrm{C}\right)\end{array}$} & \multirow{2}{*}{$\begin{array}{c}\text { Sig. } \\
\text { (2-tailed) }\end{array}$} & \multicolumn{2}{|c|}{$\begin{array}{c}\% 95 \text { Confidence Interval } \\
\text { of the Difference }\end{array}$} \\
\hline & & $\overline{\text { Fagus } \mathrm{T}\left({ }^{\circ} \mathrm{C}\right)}$ & Quercus $\mathrm{T}\left({ }^{\circ} \mathrm{C}\right)$ & & & Lower & Upper \\
\hline \multirow{4}{*}{ 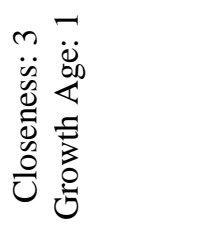 } & Ts 2015 & 37.8240 & 38.6111 & 0.7871 & 0.000 & 0.7160 & 0.8344 \\
\hline & Ts 2014 & 29.5603 & 30.5653 & 1.0050 & 0.000 & 1.0935 & 0.9701 \\
\hline & Ts 2013 & 37.3802 & 39.0060 & 1.6258 & 0.000 & 1.4457 & 1.5909 \\
\hline & Ts 2011 & 27.2850 & 28.7610 & 1.4760 & 0.000 & 1.4357 & 1.2785 \\
\hline \multirow{4}{*}{ 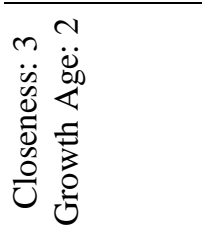 } & Ts 2015 & 38.3181 & 39.4200 & 1.1019 & 0.000 & 0.8708 & 1.3330 \\
\hline & Ts 2014 & 29.7377 & 31.2395 & 1.5018 & 0.000 & 1.3075 & 1.6960 \\
\hline & Ts 2013 & 37.5456 & 38.5041 & 0.9585 & 0.000 & 0.7271 & 1.1899 \\
\hline & Ts 2011 & 27.3950 & 28.1542 & 0.7592 & 0.000 & 0.5411 & 0.9772 \\
\hline \multirow{4}{*}{ 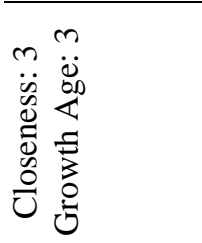 } & Ts 2015 & 41.0003 & 38.5774 & -2.4229 & 0.000 & -3.1344 & -1.7115 \\
\hline & Ts 2014 & 32.1892 & 30.6534 & -1.5358 & 0.000 & -2.1701 & -0.9015 \\
\hline & Ts 2013 & 39.4941 & 38.1819 & -1.3122 & 0.367 & -0.9950 & -0.3705 \\
\hline & Ts 2011 & 29.3145 & 28.1235 & -1.191 & 0.000 & -1.8765 & -0.5054 \\
\hline
\end{tabular}

Table 3. Surface temperature difference charts of fagus and quercus stands by years, closeness groups and growth ages.

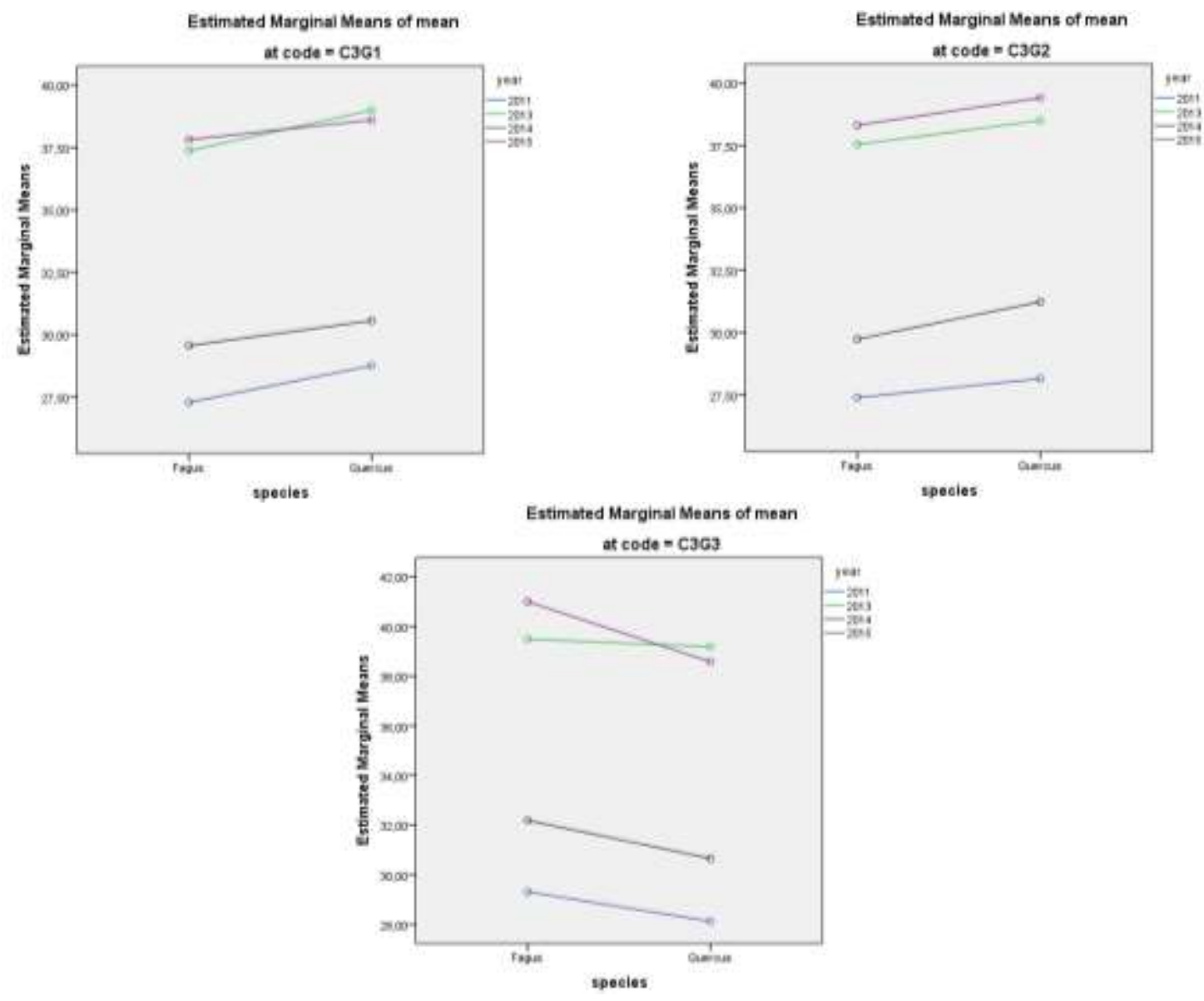




\section{CONCLUSION}

Along with the increasing urbanization, the structure of vegetation, which emerges to be a factor in the solution of many physical and ecological problems, is one of the emphasized issues of recent years. It is considered as a parameter in many topics such as improvement of the urban climate, decreasing air pollution, absorption of noise and productive energy usage. Today many of the urban governments carry out studies of landscape planning and city forestry by making use of biological features of the vegetation with a more conscious approach in order to benefit from the urban vegetation more effectively in their studies.

Green spaces have a great role in the regulation of urban climate. Shading and perspiration and vaporization processes of the vegetation have a natural cooling mechanism function in the urban areas [1]. Many studies conducted in various cities in the world have shown that urban parks and park areas in the city centers create a surface temperature difference of $2^{\circ} \mathrm{C}-8^{\circ} \mathrm{C}$ [26]. In this era when we feel the effects of global climate change more day by day, the necessity of creating future-proof plans and strategies is inevitable. In this context, the maximum advantage principal should be taken into account in the forestation practice as one of the most effective tools of the struggle. So, not only natural stands but also in the green spaces and parks which are created artificially; the species, their closure levels, growth ages, and landscaping should be tackled in a planned way.

In this article, it has been emphasized that climatic efficiency should be featured and put on the agenda in the forestation practices and regional inventories should be formed. A meticulous study is necessary for the attempt to associate the climate factor which is a far-reaching and complex issue with forest ecology which also has a complex structure. Therefore, in the study which is conducted within the scope of the information which is obtained by the available data in order to decrease the effects of various factors, the areas with similar features in the homogenous stands are compared within the borders of the directory. In this study, only Quercus and Fagus trees are compared since only these trees are found suitable to the study when certain features such as homogenous structure, closeness and growth age are evaluated together. However, in Turkey where there are essentially 37 tree species [27], it is necessary to evaluate other tree species in order to develop future-proof and serious strategies. It is obvious that an inventory which will be prepared in this respect will contribute to urban landscape practices.

\section{REFERENCES}

[1]. Kuşçu Şimşek Ç, Anthropogenic Effects Heat on Urban Climate in Istanbul: Investigation of Urban Heat Islands, Phd. Thesis, Yildiz Technical University, Graduate School of Natural and Applied Sciences, 2013.

[2]. Robine J.M, Cheung S.L, Roy S.L, Oyen H.V and Herrmann F.R, Report on Excess Mortality in Europe During Summer 2003. EU Community Action Programme for Public Health, Grant Agreement, 2007.

[3]. CNN

URL:http://edition.cnn.com/2015/06/01/asia/i ndia-heat-wave-deaths/ Retrieved June 1, 2015.

[4]. AA

(2015).

URL:

http://www.aa.com.tr/tr/dunya/557235--

fransada-sicak-hava-bir-haftada-700-can-aldi

Retrieved July 16, 2015.

[5]. İmar Panosu (2015). URL: http://imarpanosu.com/sicak-havanin-birgunluk-elektrik-faturasi-333-milyon-tl/ Retrieved June 31, 2015.

[6]. Hürriyet Newspaper (2015). URL: http://www.hurriyet.com.tr/ekonomi/2968805 1.asp Retrieved July 31, 2015.

[7]. Aitken S.N, Yeaman S, Holliday J.A, Wang $\mathrm{T}$ and Curtis-McLane S., Adaptation, Migration or Extirpation: Climate Change Outcomes for Tree Populations. Evolutionary Applications 1(2008) 95-111.

[8]. Leuzinger S and Körner C., Tree Species Diversity Affects Canopy Leaf Temperatures 
in a Mature Temperate Forest. Agricultural and Forest Meteorology 146 (2007) 29-37.

[9]. Sabnis G.M., Green Building with Concrete Sustainable Design and Construction. CRC Press, (2011) 175-226.

[10].Manning M.J, Plants in Urban Ecosystems: Essential Role of Urban Forests in Urban Metabolism and Succession Toward Sustainability. International Journal of Sustainable Development and World Ecology 15 (2008) 362-370.

[11].Barış M.E., Kent planlamas1, kent ekosistemleri ve ağaçlar (Urban planning, urban ecosystems and trees). Planlama Dergisi TMMOB Şehir Plancıları Odası Yayını, 4 (2005) 156-163.

[12].Weng Q and Quattrochi D.A., Urban Remote Sensing, CRC Press, Taylor\&Francis Group, 2007, ISBN: 0-8493-9199-7.

[13].Coll C, Caselles V, Galve J.M, Valor E, Niclo`s R, Sa'nchez J.M and Rivas R., Ground Measurements for the Validation of Land Surface Temperatures Derived from AATSR and MODIS Data, Remote Sensing of Environment 97 (2005) 288 - 300

[14].Trigo I.F, Monteiro I.T, Olesen F and Kabsch E. An Assessment of Remotely Sensed Land Surface Temperature. Journal of Geophysical Research, 113 (2008) 1-12, D17108, doi:10.1029/2008JD010035.

[15].Prihodko L. and Goward S.N., Estimation of Air Temperature from Remotely Sensed Surface Observations. Remote Sensing of Environment 60 (1997) 335-346.

[16].Kawashima S, Ishida T, Minomura M and Miwa T., Relations between Surface Temperature and Air Temperature on a Local Scale during Winter Nights. Journal of Applied Meteorology 39 (2000) 1570-1579.

[17].Unger J, Gál T, Rakonczai J, Mucsi L, Szatmári J, Tobak Z, Leeuwen B and Fiala K., Air Temperature Versus Surface Temperature in Urban Environment. In: The seventh International Conference on Urban Climate, 29 June - 3 July, Yokohama, Japan, 2009.

[18].Mutiibwa D, Strachan S and Albright T., Land Surface Temperature and Surface Air Temperature in Complex Terrain. IEEE
Journal of Selected Topics in Applied Earth Observations and Remote Sensing 8-10 (2015) 4762-4773.

[19].USGS (2016). Landsat Handbook URL: http://landsat.gsfc.nasa.gov/wpcontent/uploads/2016/08/Landsat7_Handboo k.pdf, https://landsat.usgs.gov/landsat-8-18data-users-handbook_Retrieved September 16, 2016.

[20].Van De Griend A.A and Owe M., On the Relationship between Thermal Emissivity and the Normalized Difference Vegetation Index for Natural Surfaces. International Journal of Remote Sensing 14-6 (1993) 1119-1131.

[21].Jiménez-Muñoz, Cristóbal, J., Sobrino J. A., Sòria G., Ninyerola M. and Pons X., Revision of the Single-Channel Algorithm for Land Surface Temperature Retrieval from Landsat Thermal-Infrared Data, IEEE Transactions on Geoscience and Remote Sensing, vol. 47-1 (2009) 339-349.

[22].Abreu-Harbich L.V, Labaki L.C and Matzarakis A., Different Trees and Configuration as Microclimate Control Strategy in Tropics. In: Proceedings of the ICUC8 - 8th International Conference on Urban Climates, 6-10 August, UCD, Dublin Ireland, 2012

[23].Leuzinger S, Vogt R. and Körner C., Tree Surface Temperature in an Urban Environment. Agricultural and Forest Meteorology, 150 (2010) 56-62

[24].Lin B.S and Lin Y.J., Cooling Effect of Shade Trees with Different Characteristics in a Subtropical Urban Park. Hort Science 45-1 (2010) 83-86.

[25].Abreu-Harbich L.V, Labaki L.C and Matzarakis A., Effect of Tree Planting Design and Tree Species on Human Thermal Comfort in the Tropics. Landscape and Urban Planning 138 (2015) 99-109.

[26].Kuşçu Şimşek Ç., An Analysis of Micro Climatic Influences of Middle-scale Urban Parks: The Case of Gezi Park, Maçka Park and Serencebey Park, Metu JFA 33-2 (2016) $1-17$.

[27].OGM, Orman atlas1 [Forest atlas]. Orman Genel Müdürlüğü Yayını, 2013. 